\title{
PELAYANAN INTERNATIONAL TOURISM DI KABUPATEN BANYUWANGI MELALUI PROGRAM KURSUS BAHASA ASING BERBASIS DESA
}

\author{
Moh. Mahmud ${ }^{1}$, Maskur ${ }^{2}$ \\ Institut Agama Islam Darussalam Blokagung Banyuwangi \\ Email: mohmahmud060578@gmail.com¹, masmaskur278@yahoo.co.id ${ }^{2}$
}

\begin{abstract}
The Foreign Language Course program based on the village is a government program in Banyuwangi Regency with budgeting from the APBD for a minimum of 3 months each year. The activity was carried out in order to equip community members regarding foreign language skills as a provision in increasing service to foreign tourists who came from various parts of the world to the Banyuwangi Regency. This study uses a qualitative approach in which researchers go directly and interact directly within the tourism community and foreign language courses to explore data and information related to the activity program. The findings in the field that the Banyuwangi Regency government in order to enhance the community in communication skills in terms of foreign languages, the Government has carried out The Foreign Language Course program based on village conducted in all villages in Banyuwangi with a budget from the Regional Budget.
\end{abstract}

\section{Keywords: Service, International Tourism, Foreign Language Course}

\begin{abstract}
Abstrak
Program Kursus Bahasa Asing brerbasis desa merupakan program pemerintah Kabupaten Banyuwangi dengan anggran dari APBD yang diseelnggaran selama mainal 3 bulan setiap tahun. Kegiatan tersebut dilakukan dalam rangka membekali anggota masyarakat mengenai kemampuan berbahasa asing sebagai bekal dalam peningkatan pelayaanan kepada wisatawan asing yang datang dari berbagai belahan dunia ke Kabupaten Banyuwangi. Penelitian ini menggunakan pendekatan kualitatif yang mana peneliti terjun langsung dan berinteraksi langsung di dalam komunitas pariwisata dan kursus bahasa asing untuk menggali data-data dan informasi terkait program kegiatan tersebut.Hasil temuan di lapangan bahwa dalam hal peningkatan kemampuan komunikasi masyarakat dalam hal bahasa asing, pemerintah telah melaksanakan kursus bahasa asing berbasis desa yang dilaksanakan di semua desa yang ada di wilayah Banyuwangi dengan anggaran darari APBD .
\end{abstract}

Kata Kunci: Pelayanan, Pariwisata Internasional, Kursus Bahasa Asing 


\section{A. Pendahuluan}

Pariwisata merupakan kegiatan yang berupa perjalanan dalam rangka mendapatkan kenikmatan, meraih kepuasan, mengetahui informasi, memperbaiki dan meningkatkan kesehatan, menikmati olahraga maupun istirahat, menjalankan tugas, dan lain-lain. Pengertian yang luas dari pariwisata adalah perjalanan dari suatu tempat ke tempat lain, yang bersifat sementara, dilakukan kelompok maupun perorangan, dalam usaha mencari keseimbangan atau keserasian dan kebahagiaan dengan lingkungan hidup dalam dimensi sosial, budaya, alam dan ilmu. Sebuah perjalananakan dikatakan sebagai perjalanan wisata bila memenuhi tiga indikator yang diperlukan, yakni bersifat sementara, sukarela (Voluntary), dan tidak bekerja yang sifatnya komersial (Spillane dalam Siallagan, 2011)

Pariwisata internasional (international tourism) yang dimaksud dalam penelitian ini adalah kaitannya dengan destiansi wisata yang diharapkan wisatawan yang datang akan datang dari berbagai penjuru dunia dari dunia internasional. Pariwisata internasional merupakan kegiatan perjalanan antarnegara maupun benua yang bermaksud untuk bersenang-senang tanpa mencari nafkah dan juga menggunakan dananya sendiri serta dilakukan dalam skala antarnegar maupun benua yang mana nantinya akan melibatkan transportasi yang lebih modern dan mampu malakukan perjalanan jarak jauh, seperti kapal pesiar, kapal angkutan penumpang laut, pesawat terbang, dan lain-lain.

Pemerintah kabupaten Banyuwangi telah ditunjuk Pemerintah pusat sebagai perwakilan Indonesia yang berhasil mendapatkan penghargaan terbaik di ajang United Nations World Tourism Organization (UNWTO) Awards kedua belas yang dilaksanakan di Madrid, Spanyol. Kabupaten Banyuwangi yang mendapat julukan 'Sunrise of Java' telah berhasil meraih penghargaan The Winner of Re-Inventing Government in Tourism dalam kategori Innovation in Public Policy Governance (Inovasi Kebijakan Publikdan Tata Kelola Pemerintahan).

Tujuan dari dilaksanakan penelitian ini adalah sebagai berikut: (1) Mengetahui bentuk-bentuk pelayanan dan langkah-langkah PemerintahKabupaten Banyuwangi dalam rangka meningkatkan Pelayanan InternationalTourism terkait 
program Kursus Bahasa Berbasis Desa (2) Mengetahui seberapa efektif program Kursus Bahasa Berbasis Desa terhadap Pelayanan International Tourism.

\section{B. Landasan Teori}

Menurut Groonros dalam Ratminto dan Atik (2005) pelayanan adalah merupakan suatu kegiatan atau serangkaian kegiatan yang bersifat tidak dapat diraba yang timbul akibat adanya hubungan antara konsumen dengan karyawan atau antara hal-hal lain yang disediakan oleh badan/perusahaan pemberi pelayanan yang bertujuan untuk memecahkan permasalahan konsumen atau pelanggan. Pada hakikatnya pelayanan merupakan serangkaian kegiatan yang berkesinambungan, sehingga proses pelayanan tersebut berlangsung secara rutin dan terus menerus yang meliputi seluruh aspek kehidupan organisasi dalam kelompok masyarakat. Proses yang dimaksudkan dilakukan sehubungan dengan saling memenuhi kebutuhan antara penerima dan pemberi pelayanan.

Pariwisata internasional dalam artian luas yaitu kegiatan kepariwisataan yang berkembang dalam wilayah suatu negara selain kegiatan "domestic tourism" juga dikembangkan "foreign tourism" dimana didalamnya termasuk "in bound tourism" dan "out going tourism". Jadi, selain adanya lalu lintas wisata studi dalam negeri sendiri, juga ada lalu lintas wisatawan dari luar negeri, maupun dari dalam negeri ke luar negeri. International Tourism juga dikatakan world tourism, yaitu kegiatan kepariwisataan yang berkembang di seluruh negara di dunia.

Dalam Peraturan Menteri Pendidikan dan Kebudayaan Republik Indonesia Nomor 81 Tahun 2013 tentang Pendirian Satuan Pendidikan Non formal Bab I Ketentuan Umum Pasal 1 butir ke empat dinyatakan bahwa Lembaga Kursus dan Pelatihan selanjutnya disebut LKP adalah satuan pendidikan non formal yang diselenggarakan bagi masyarakat yang memerlukan bekal pengetahuan, keterampilan, kecakapan hidup, dan sikap untuk mengembangkan diri, mengembangkan profesi, bekerja, usaha mandiri, dan/atau melanjutkan pendidikan ke jenjang yang lebih tinggi.

Direktorat Pembinaan Kursus dan Kelembagaan (2010) memberikan pengertian kursus sebagai proses pembelajaran tentang pengetahuan atau keterampilan yang diselenggarakan dalam waktu yang pendek oleh suatu lembaga 
yang berorientasi pada kebutuhan masyarakat dan dunia usaha/industri. Chaer (2009:37) mengemukakan teori terkait dengan bahasa asing, adanya sebuah istilah bahasa target yang berupa bahasa yang sedang dipelajari untuk dikuasai. Perwujudan bahasa target tersebut dapat berupa bahasa ibu/mother language atau bahasa pertama (B1), bahasa kedua (B2) atau second language maupun bahasa asing (BA) atau foreign language. Definisi bahasa kedua (B2) tidak sama dengan bahasa asing (BA).

Fachrurrozi dan Erta Mahyuddin (2011:5) menyatakan bahwa ada beberapa kajian pembelajaran bahasa asing memiliki sejarah panjang hingga beberapa ahli bahasa/linguistik menyimpulkan bahwa ada tiga istilah pokok dalam kajian bahasa, yakni Pendekatan, Metode dan Teknik. Pendekatan merupakan bentuk hipotesa-hipotesa dan kepercayaan-kepercayaan terhadap sifat alami suatu bahasa, pembelajaran dan pengajarannya.

Guyer-Freuler dalam Pendit (1999:38) menjelaskan bahwa pengertian pariwisata merupakan fenomenakebutuhan akan pergantian suasana kesehatan, penilaian secara sadar yang menumbuhkan rasa cinta terhadap keindahan alam raya dan bertambahnya interaksi berbagai kelompok masyarakat dan kelas manusia sebagai dampak daripada perkembangan perdagangan, perniagaan,industri, dan penyempurnaan dari alat-alat ekspedisi.

\section{Metode Penelitian}

Penelitian ini menggunakan pendekatan kualitatif yaitu salah satu metode penelitian yang merupakan prosedur yang dapat menghasilkan data diskriptif berupa tulisan dan lisan dari perilaku orang-orang yang dapat diamati. Dalam hal ini peneliti terjun langsung kepada pihak-pihak yang terkait dengan pelayanan pariwisata, sehingga mendapatkan data yang akurat.Penelitian ini dilakukan di Kabupaten Banyuwangi dengan fokus kegiatan pada pelayanan internasional pariwisata dan kursus bahasa asing yang kedua-duanya saling terkait.

Dalam rangka menjaring data, maka penelitian ini dilakukan dengan menggunakan tiga pendekatan yaitu: (1) wawancara mendalam (indept interview), (2) pengamatan peran (Participan Observation) serta (3) Dokumentasi (Documentation). 
Untuk mendapatkan informasi yang mendalam, peneliti menentukan informan dengan menggunakan tehnik snow ball (bola salju) yakni penggalian data melalui wawancara mendalam dari satu informan keinforman lain dan seterusnya sampai peneliti tidak menemukan informasi lagi, jenuh, dan informasi yang tidak berkualitas (Hamidi, 2004). Dalam penelitian ini nantinya akan menentukan informan pada dinas kebudayaaan dan pariwisata terkait pelayanan pariwisata, dinas pendidikan terkait kursus bahasa asing, pelaksana lapangan kursus bahasa asing, pihak pelaku pelayan/agen wisata, instruktur dan peserta kursus bahas asing, dan wisatawan asing yang mendapatkan pelayanan.

Teknik analisis data yang dipergunakan dalam penelitian ini dengan metode kualitatif adalah dengan interaktif model, yang terdiri dari tiga komponen yaitu: reduksi data (data reduction), penyajian data (data display) penarikan serta pengujian data (drowing and ferivying conclution).

\section{Hasil}

Berdasarkan data sejarah mengenai Kabupaten Banyuwangi, tidak akan terlepas dari sejarah Blambangan, karena sepanjang sejarah Blambangan sekitar tanggal 18 Desember 1771 merupakan peristiwa sejarah yang tertua yang patut diangkat sebagai cikal bakal hari jadi Banyuwangi. Sebelum terjadi peristiwa puncak perang Puputan Bayu sebenarnya ada peristiwa lain yang mendahuluinya, yang juga penuh dengan heroik-patriotik, yaitu peristiwa penyerangan para pejuang patriot Blambangan yang dipimpin oleh Pangeran Puger (Putra Wong Agung Wilis) ke benteng VOC di Banyualit pada tahun 1768

Penduduk Banyuwangi cukup beragam. Namun Mayoritas dari mereka adalah Suku Osing, selain itu juga terdapat Suku Madura yang kebanyakan tinggal di kecamatan Wongsorejo, Muncar, Glenmore dan Kalibaru) dan ada juga Suku Jawa yang cukup signifikan. Perkembangan pariwisata di Banyuwangi selama kurun waktu kurang 10 tahun mengalami peningkatan yang sangat pesat. Hal ini dikarenakan semakin dikembangkan potensi masyarakat dan lingkungan di Banyuwangi baik dengan menciptakan destinasi-destinasi paiwisata maupun diselenggarakannya festival-festival dari berbagai tradisi, budaya, profesi dan lain-lain. Berdasarkan paparan yang di sampaikan oleh Bapak Sandi Kabid 
Pemasaran di Dinas Kebudayaan dan Priwisata bahwa pada tahun ke tahun semangat pariwisata di Banyuwangi senantiasa ditingkatkan, dikembangkan dan senantiasa ada evaluasi.

Pemerintah Kabupaten Banyuwangi dalam meningkatkan kunjungan wisata dengan menggalakkan 3 hal yang merupakan rangkaian pelayanan kepada wisatawan, baik domestik maupun mancanegara, Hal ini sebagaimana disampaikan oleh Bapak Sandi, Kepala Bidang Pemasaran Pariwisata di Dinas Kebudayaan dan Pariwisata Kabupaten Banyuwangi bahwa 3 komponen tersebut adalah Akses, Amunitas dan Atraksi yang mana semuanya sangat berkaitan dengan bentuk-bentuk pelayanan dan langkah-lankah pemerintah dalan meningkatkan pelayanan kepada wisatawan/turis, baik lokal maupun asing.

Aksesmerupakan bentuk pelayananuntuk meningkatkan pelayanan wisatawan yang berkunjung ke Banyuwangi agar senentiasa menarik dan meningkat maka Pemerintah Kabupaten Banyuwangi membuat inovasi-inovasi di antarnya ditingkatkan alat transportasi yang lebih efaktif dan nyaman yaitu dibukanya Bandara dan jadwal penerbangan yang semakin baik. Selain itu akses akses trensportasi lokal yang meliputi taksi online maupun ofline, ojek offline maupun online, Bus, dan transportasi yang lain.

Selain itu penyediaan fasilitas dan pelayanan semakin ditingkatkan dan bervariasi sejalan dengan tingkat perkembangan banyaknya wisatawan yang berkunjung. Perkembangan tempat perbelanjaan seperti toko, mall, warung, kafe dan lain-lain serta jasa pelayanan pada destinasi pariwisata dimulai dengan adanya pelayanan jasa kebutuhan sehari-hari, seperti warung makanan, warung minuman atau penjual jajanan lainnya, kemudian dikemabangkan jasa-jasa perdagangan seperti pramuniaga, tukang-tukang atau jasa pelayanan lainnya, selanjutnya jasa untuk kenyamanan dan kesenangan seperti toko pakaian, toko perabot rumah tangga, toko souvenir, toko asesoris daln lain-lain, kemudian dikembangkan lagi pada jasa yang menyangkut keamanan dan keselamatan seperti rumah sakit, klinik kesehatan, apotek, toko jamu, polisi dan pemadam kebakarandan lain-lain yang pada akhirnya dikembangkan lebih lanjut pada bidang-bidang yangterkait dengan jasa penjualan barang mewah. 
Perbaikan dan perawatan Infrastruktur yang memadai juga sangat diperlukan dalam rangka mendukung jasa pelayanan dan fasilitas pendukung. Pembangunan infrastruktur secara tidak langsung juga memberi manfaat dan kenyamana pada penduduk setempat di samping juga sangat mendukung pengembangan pariwisata. Pembangunan infrastuktur tersebut selain menyangkut bidang transportasi seperti jalan, badara, pelabuhan, jalan kereta api, taerminal angkutan umum dan lain-lain, tetapi juga terkait penyediaan saluran air minum, penerangan listrik, dan juga saluran pembuangan limbah.

Amunitasadalah bentuk pelayanandalam rangka meningkatkan pelayanan wisatawan yang datang dari luar kota bahkan mancanegara maka di Banyuwangi dibuka beberapa hotel dan Home stay. Hotel tersebut disiapkan di kota untuk menginap wisatawan yang datang dari tempat jauh,diantaranya Hotel Aston, Hotel Santika, Hotel e'Royal dan lain-lain. Wistawan yang datang ke Banyuwangi ada yang bertujuan berlibur dan rekresai ada juga yang study banding kemajuan Banyuwangi dan sekaligus rekreasi yang datang dari berbagai Kabupaten di Indonesia. Hotel-hotel tersebut biasanya padat pada saat hari kerja, Senin sampai Kamis. Sedang homestay terletak di dekat dekat destinasi wisata yang jauh dari kota. Konsep Home stay adalah rumah masyarakat yang empunyai kamar minimal 6 kamar, maka 3 kamar untk keluarga dan sisanya disewakan kepada para wisatawan dengan harga yang bervariasi minimal Rp 250.000 sehari semalam. Pada tahun 2010 jumlah home stay di Banyuwangi hanya 10 buah, pada tahun 2018 sudah mencapai 510 buah

Atraksi Pemerintah Kabupaten Banyuwangi melaui dinas-dinas terkait menyelenggrakan kegiatan festival-festival dari berbagi bentuk. Pada tahun 2018 ada 77 ferstival yang diselenggran baik yang tingkat lokal, nasional maupun internasional. Menurut Bapak Ainur Rofiq, S.Sos. bahwa dari kesekian ferstival tersebut ada 3 event yang diikuti oleh peserta dari anca negara, yaitu International Tour D'Ijen Banyuwangi, Festival International BMX dan Banyuwangi Ijen Green Run. Sedang festival yang paling favorit adalah BEC (Banyuwangi Etno Carnival), Gandrung Sewu dan Festival Kopi Sepuluh Ewu.

Selain mempromosikan pariwisata di Banyuwangi dengan menggelar festival-ferstival maupun ikut pameran pariwisayta di dunia Internasional juga 
menyelenggaran kursus Bahasa Asing dalam rangka membekali masyarakat kemampuan bahasa asing yang meripakan sarana berkomunikasi dengan wisatawan asing sebagai salah satu bentuk pelayanan kepada mereka agar merasa nyaman dan krasan berwisata di Bannyuwangi.

Namun ada yang perlu dikritisi berdasarkan komentar yang disampaikan oleh peneliti adalah setiap agenda atraksi festival tersebut beban biaya dilimpahkan kepada peserta, sebesar apaun sehingga ada kesan pemerintah mencari gebyar yang sebenarnya ada sebagaian masyarakat bawah yang menjerit ketika harus mengeluarkan biaya yang lumayan besar demi untuk menyertkan anak-anaknya dalam salah satu event festival tersebut, yang padahal masyarakat yang mersakan dampak positif hanya yang ada disekitar lokasi festival.

Sebagai contoh adalah festival Gandrung sewu ataupun Banyuwangi Etnho Carnival, peserta harus merogoh kocek/ mengeluarkan biaya banyak untuk menjadi peserta festival tersebut, namun dampak positif yangkembali kepada mereka belum jelas, karena mereka berasal dari berbagai desa di wilayah Kabupaten Banyuwangi, yang mana pelaksanaan festival tersebut di wilayah kota. Sehingga yang merasakan efek ekonomi dan lain-lain secara otomatis juga warga masyarakat yang ada di sekitar lokasi/kota.

Dalam rangka meningkatkan kualitas Sumber daya manusia di Kabupaten Banyuwangi, dan juga dalam rangka meningkatkan pelayanan kepada wisatawan asing maka Pemerintah Kabupaten Banyuwangi menggelar Kursus Bahasa Asing Berbasis Desa. Kursus tersebut digelar secara gratis di desa-desa yang ada di wilayah Kabupaten bayuwangi. Adapun basa asing yang diajarkan ada 3 yaitu Bahasa Inggris, Arab, dan Mandarin. Kursus selain dalam rangka ikut emncerdaksn kehidupan berbangsa juga diharapkan memberi kompetensi tambahan bagi warga, terutama generasi muda di desa. Kegiatan Kursus tersebut juga sekaligus dalam rangka pemerataan pendidikan. Karena sementara ini bahasa asing itu hanya diikuti oleh orang-orang yang punya biaya dan tinggal di wilayah kota saja. Maka sebagai langkah Pemerintah Kabupaten Banyuwangi program tersebut gratis dan digelar di desa-desa di wilayah Banyuwangi.

Program kursus ini sudah berjalan sejak awal Mei tahun 2015, Penguasaan bahasa asing diperlukan untuk menyambut integrasi masyarakat 
antarnegara, khususnya dalam menghadapi Masyarakat Ekonomi ASEAN (MEA). Selain itu, juga untuk menyambut perkembangan pariwisata Banyuwangi yang kian pesat. Dengan fasilitasi kursus gratis tersebut, semua warga di desa berpeluang menguasai bahasa asing. Kalau selama ini kan lembaga kursus kebanyakan ada di daerah kota dan itu pasti berbayar. Sekarang kami fasilitasi gratis supaya semua bisa ikut dan maju bareng-bareng, kata Anas.

Pelaksanaan waktu kursus berdasarkan kesepakatan antara instruktur dan peserta, kebanyakan kursus tersebut dilaksanakan pada sore atau malam hari agar tak mengganggu aktivitas warga yang bekerja. Tempat kursuspun bervariasi sesuai kesepakatan, ada yang di balai desa atau tempat publik di desa sehingga bisa lebih guyub dan warga lain yang belum mengikuti kursus bisa termotivasi.

Pada tahun 2017 telah terbentuk 205 kelompok kursus bahasa Inggris, 27 kelompok bahasa Mandarin, dan 20 kelompok bahasa Arab. Di semua desa/kelurahan telah terbentuk kelompok yang masing-masing beranggotakan sekitar 12 orang. Ada kelompok yang gabungan dari dua desa bersebelahan karena meminati satu bahasa yang sama, namun pesertanya kurang dari 12 orang. Jadi misalnya di Desa A ada 3 warga ingin belajar Mandarin, lalu Desa B ada 7 warga, ya kami gabungkan jika desanya berdekatan.

Dalam pelaksanaanya, satu desa membentuk satu kelompok belajar yang akan dipandu seorang tutor. Tutornya dari guru bahasa asing di sekolah-sekolah dan Lembaga Kursus dan Pelatihan. Desa dipersilakan memilih satu bahasa sesuai minat warganya. Bila ternyata dalam satu desa ada warga yang minat bahasanya beda, nanti bisa datang ke desa yang menyelenggarakan kursus bahasa yang mereka minati. Lokasi kursus ditetapkan sesuai kesepakatan warga, bisa di balai desa, tempat ibadah, hingga ruang Taman Kanak-Kanak. Jadwalnya juga sesuai kesepakatan warga.

Menurut Bapak Sunari dari Dinas Pendidikan dalam setiap tahunnya Pemerintah Kabupaten menganggarkan Rp 735 pada tahun 2015 yang diikuti sekitar 3500 peserta, pada tahun 2016 dianggarkan 100 juta yang dilaksanakan di dua kecaatan saja Kabat dan Wongsorejo. Dan kemudian pada tahun 2018 pemerintah menganggarkan 1 milyar yang diikuti oleh sekitar 3000 perseta dan dilaksanakan di seluruh desa di Kabupaten Banyuwangi. Anggaran tersebut 
diperuntukkan untuk keperluan operasional, mulai honorarium tutor, ATK, modul belajar, dan peralatan penunjan lainnya.

Kursus Bahasa Asing ini berlangsung selama tiga bulan dalam satu tahun yang dimulai pada Bulan Maret. Semua peserta wajib menyelesaikan paket belajar selama 201 jam. Informasi dan sosialisasi disampaikan lewat Unit Pelaksana Teknis Dinas di kecamatan-kecamatan dalam waktu dekat ini. Pada tahun 2018 kegiatan kursus bahasa asing tidak dilaksanakan lagi karena anggarannya tidak ada. Catatan pasti tentang alumni/produk kursus bahasa asing yang terjun di sektor pariwisata secara langsng belum diketahui karena belu adanaya tindak lanjut pendataan pada hal tersebut. Ada tiga tempat yang asih tetap eksis melaksanakan kursus bahasa asing meskipun tidak ada anggaran dari peerintah Kabupaten Banyuwangi dengan biaya swadaya, bahkan ada yang membentuk lokasinya sebagai kampung Inggris, yaitu Desa Bajulmmati, Desa Wringinrejo dan Desa Jambewangi.

Teknis pelaksanaan kursus bahasa asing berbasis desa tersebut diserahkan kepada lembaga kursus Desy Education, satu-satunya lembaga kursus yang belau kelola yang telah meraih/mendapatkan Juara 1 Nasional, Pengelola LKP Terbaik, Juara Nasional, LKP Berprestasi, Kinerja Lembaga Predikat A (Unggul), Terakreditasi BAN PNF Kemdikbud R.I, Penyelenggara Resmi TOEFL ITP Center dan Tempat Uji Kompetensi Bahasa Inggris ( TUK - BIG ) dari Dinas Pendidikan Nasional.

Adapun desain plan dari kursus bahasa asing tersebut adalah sebagai berikut: (1) Dihimpun dan diselesksi para calon tutor Bahasa dari setiap desa untuk diberikan pelatihan agar sama persepsi, visi dan misi sehingga tujuan kegiatan tersebut bisa terwujud, (2) Dilaksanakan di setiap desa dengan kuota 12 peserta di tiap desa yang dilaksanakan sesuai kesepakatan dari pihak tutor dan peserta di setiap desa.(3) Diadalakan evaluai periodik setiap bulan untuk mengetahui sebarapa peningkatan dan serapan kursus tersebut, (4) Di akhir pelaksanaan akan diaadakan evaluasi secara menyeluruh baik tingkat Kabupaten Banyuwangi bahkan sampai tingkat

TUK BIG (Tes Uji Kompetensi Bahasa Inggris para peserta kursus Bahasa Asing Berbasis Desa pada tahun 2015 diikuti oleh 3615 peserta untuk 
tingkat kabupaten Banyuwangi dengan sertifikat yang dikeluarkan oleh Dinas Pendidikan Kabupaten Banyuwangi. Dari 3615 peserta tersbut yang lolos bisa mengikuti TUK BIG nasional hanya $10 \%$ atau sekitar 300 peserta. Setelah mengikuti tes yang lulus hanya $50 \%$ nya atau 150 peserta

Pada tahun 2016 dan 2017 Tes dilakasnakan di masing-masing lembaga pelaksana/desa pelaksana kursus bahasa asing utuk lebih fokus dan disesuaikan dengan kondisi daerah masing-masing, tidak distandarkan sebagaimana tahun sebelumnya. Di ataranya ujian langsung di bawa ke lokasi wisata dan praktik langsung berbahasa asing dengan para native speaker, agar hasilnya secara real bisa diketahui dan dipraktikan, tidak hanya teori bahasa saja.

\section{E. Pembahasan}

Bentuk-bentuk pelayanan dan langkah-langkah Pemerintah Kabupaten Banyuwangi dalam meningkatkan Pelayanan International Tourism melalui program Kursus Bahasa Berbasis Desa.

Pada era globalisasi dan melenia, teknologi menuntut terwujudnya efesiensi dan efektivitas dalam pelayanan publik, yang di antaranya dalam bidang pariwisata. Salah satu wilayah dengan potensi pariwisata yang sangat baik adalah Kabupaten Banyuwangi. Langkah pemerintah dalam rangka untuk terus meningkatkan jumlah kunjungan wisata tersebut, adalah dengan melakukan sebuah inovasi dalam hal pelayanan informasi pariwisata (tourism information service) yang diawali dari program inovasi daerah bertema B-Diso (Banyuwangi Digital Society).

Dalam rangka pengembangan content e-government telah diluncurkan sebuah inovasi sebuah pelayanan informasi pariwisata melalui aplikasi berbasis android "Banyuwangi Tourism" oleh Dinas Pariwisata Kabupaten Banyuwangi. Aplikasi tersebut merupakan bantuan dari Corporate Social Responsibility (CSR) dari PT. Telkom. Kualitas pelayanan informasi dari aplikasi ini cukup baik. Namun dalam pelaksanaannya masih mengalami hambatan-hambatan dari kualitas dan jumlah SDM (Sumber Daya Manusia) di bidang TI, sehingga aplikasi tersebut terhenti akibat terserang hacker/peretas.

Atas usaha penigkatan pelayanan pariwisata tersebut sepanjang tahun 2017 jumlah kunjungan wisatawan ke Banyuwangi telah melampaui target 2,3 
juta sebagaimana yang telah ditetapkan oleh Pemerintah kabupaten Banyuwangi. Sejak Januari hingga Desember 2017, Jumlah kunjungan wisata di Banyuwangi terdapat sekitar 4,6 juta wisatawan lokal dan 92 ribu wisatawan asing/internasional.

Berdasarkan wawancara dengan Bapak Sandi dan Ainur Rofiq dari Dinas Kebudayaan dan Pariwisata Banyuwangi didapat data bahwa dalam masa beberapa tahun terakhir ini, yakni dimulai dari tahun 2010 hingga 2017 kunjungan wisata ke Banyuwangi terus mengalami peningkatan. Tercatat pada tahun 2010 kunjungan wisata Banyuwangi sekitar 497 ribu wisatawan lokal dan 5.205 wisatawan asing. Dalam penghitungan yang dilakukan oleh Dinas Pariwisata Kabupaten Banyuwangi dari tahun 2010 hingga tahun 2016, kunjungan wisata mengalami pelojakan menjadi 2,7 juta wisatawan lokal dan 75 ribu wisatawan asing. "Untuk tahun 2017 kunjungan wisatawan domestik mencapai 4,6 juta wisatawan," ungkap Kabid Pemasaran Dinas Kebudayaan dan Pariwisata Bapak Sandi.

Dari sekian wisatawan yang berlibur di Banyuwangi, ada tiga destinasi wisata yang menjadi favorit wisatawan. Tiga tempat itu adalah, Gunung Ijen, Pulau Merah, dan Bunder Bangsring. Di tiga tempat tersebut terhitung paling banyak di kunjungi wisatawan sepanjang tahun 2017.Target Kunjungan Wisata yang dicangankan pada tahun 2018, lebih tinggi dari tahun sebelumnya. Jumlah wisatawan lokal ditarget 5 juta wisatawan dan wisatawan asing ditarget 100 ribu wisatawan. Selain menampilkan dan menjual pesona alam dan kekayaan senibudaya, Pemerintah kabupaten Banyuwangi juga akan menjual potensi wisata dalam bentuk pelayanan publik.

Dampak dari peningkatan kunjungan wisatawan di Banyuwangi diantaranya menjadi pengungkit perekonomian lokal. Pendapatan perkapita masyarakat meningkat dari Rp. 20.08 juta/orang pertahun pada 2011 menjadi Rp. 43,65 juta/orang pertahun pada 2017. Sedangkan angka kemiskinan Banyuwangi turun dari 20,09 (2011) persen menjadi 8,64 persen (2017). 


\section{Seberapa efektif program Kursus Bahasa Berbasis Desa terhadap Pelayanan} International Tourism.

Berdasarkan data yang dihimpun bahwa kunjungan wisatawan lokal maupun asing terus mengalami peningkatan ada indikasi karana adanya peningktan dan perbaikan pelayanan kepada mereka meski sepisikasi apakah itu karena diadakannya kursus bahasa asing atau bukan karena belum adanya data valid produk kursus bahasa asing yang terjun sebagai guide wisatawan asing, namun dapat disimpulkan bahwa kursus bahsa asing tersebut sangat mendukung dan efektif dalam rangka peningkatan pelayanan wisatwan asing, karena ada bukti nyata adanya peningkatan jumlah kunjngan wisatawan asing yang datang ke Banywuangi

\section{F. Kesimpulan}

Pariwisata di Banyuwangi mengalami peningkatan pengunjung yang signifikan sejak tahun 2010 sampai saat ini. Ada beberapa destinasi wisata yang dikembangkan dan diberdayakan agar dapat lebih indah dan menarik untuk dikunjungi. Selain itu juga dipersiapkannya beberapa bentuk pelayanan yang pokok maupun pendukung dalam usahanya untuk meningkatkan pengunjung wisata yang datang berkunjung di Banyuwangi yaitu: (a) Akses (b) Amenitas dan (c) Atraksi yang ketig-tiganya bisa menjadi bentuk publikasi dan promosi pariwisata Banyuwangi

Bentuk pelayanan yang lain dalam bidang kepariwisataan adalah komunikasi yang baik yang di antaranya adalah bahasa asing (Inggris, Arab dan Mandarin) untuk menyambut dan melayani wisatawan yang menggunakan bahasa-bahasa tersebut, sehingg Pemerintah Kabupaten Banyuwangi dengan pihak terkait melaksanakan kursus bahasa asing berbasis desa yang diperuntukkan bagi warga masyarakat untukmemberikan bekal bahasa asingsebagaisalah satu saran berkomunikasi dalam dunia pariwisata maupun dunia kerja yang lain. untuk melaksanakan kursus bahasa asing yaitu Desy Education. 


\section{Daftar Pustaka}

Anthony Fransisko Siallagan. 2011. Analisis Permintaan Wisatawan Nusantara Objek Wisata Batu Kursi Siallagan, Kecamatan Simanindo, Kabupaten Samosir. / Journal.

Atik, dan Ratminto. 2005. Manajemen Pelayanan, disertai dengan pengembangan model konseptual, penerapan citizen's charter dan standar pelayanan minimal. Yogyakarta: Pustaka Pelajar

Arikunto, Suharsimi. 2002. Prosedur Penelitian Suatu Pendekatan dan Praktek. Jakarta: Rineka Cipto

Chaer, Abdul. 2009. Sintaksis Bahasa Indonesia: pendekatan Proses. Jakarta: Rineka Cipta

Direktorat Pembinaan Kursus dan Kelembagaan ,2010

Fachrurrozi dan Mahyuddin. 2011. Pembelajaran Bahasa Asing (Metode Tradisional \& Kontemporer). Jakarta : Bania Publishing

Hamidi, 2004, Metode Penelitian Kualitatif: Aplikasi Praktis Pembuatan Proposal dan Laporan Penelitian, Malang: UMM Press

http://erinnurianti.blogspot.com/2011/03/konsep-dasar-kursus.html. Diakses 22 Oktober 2018

Peraturan Menteri Pendidikan dan Kebudayaan Republik Indonesia Nomor 81 Tahun 2013 tentang Pendirian Satuan Pendidikan Non formal

Spillane J.J,1987, Pariwisata Indonesia Sejarah dan Prospeknya, Yogyakarta, Kanisius, 150 Halaman

Undang-Undang Republik Indonesia Nomor 10 Tahun 2009 tentang kepariwisataan.

UNWTO. 2011. Religious Tourism in Asia and the Pacific. Diakses Agustus 4, 2018 ,

dari http://publications.unwto.org/sites/all/files/pdf/110325_religious_tourism_ excerpt.pdf 80 